\title{
EPS İle İkame Edilmiş Uçucu Küllü Geopolimer Hafif Harcın Fiziksel, Mekanik ve Isıl Geçirimlilik Özelliklerinin İncelenmesi
}

\author{
${ }^{* 1}$ Serhan İlkentapar, ${ }^{2}$ Halil Eren \\ *1Erciyes Üniversitesi İnşaat Mühendisliği Bölümü, serhan@erciyes.edu.tr, \\ ${ }^{2}$ Erciyes Üniversitesi İnşaat Mühendisliği Bölümü, halileren7@gmail.com,
}

Araștırma Makalesi

Geliş Tarihi: 02.04.2020

Kabul Tarihi: 12.09 .2020

$\ddot{O} \mathbf{z}$

Bu çalışmada genleştirilmiş polistiren (EPS) kullanılarak uçucu kül tabanlı geopolimer hafif harçlar imal edilmiştir. EPS hacimce $\% 20, \% 40, \% 60, \% 80, \% 100$ oranlarında ırmak kumu ile yer değiştirerek, EPS agregalı geopolimer harçların üretimi gerçekleştirilmiştir. EPS'li geopolimer harçlar, F sınıfı uçucu külün sabit oranda $\mathrm{NaOH}$ ile aktive edilmesiyle, $75^{\circ} \mathrm{C}$ 'de 24 ve 48 saat sıcaklık kürüne tabii tutulmuştur. Sıcaklık kürü sonrası geopolimer hafif harç numunelerin fiziksel özellikleri, mekanik özellikleri ve 1sıl geçirimlilik özellikleri araştırılmıştır. Ayrıca $300^{\circ} \mathrm{C}, 600{ }^{\circ} \mathrm{C}, 900{ }^{\circ} \mathrm{C}$ 'de yüksek sıcaklık sonrası geopolimer harçların eğilme, basınç dayanımları ve geopolimer hamurların mikro yapısı incelenmiştir. Elde edilen sonuçlara göre 24 saat sıcaklık kürüne tabii tutulan hafif geopolimer harçların birim ağırlıkları 1,93 ile $0,61 \mathrm{~g} / \mathrm{cm}^{3}$ arasında, 48 saat sıcaklık kürüne tabii tutulan hafif geopolimer harçların birim ağırlıkları 1,87 ile $0,66 \mathrm{~g} / \mathrm{cm}^{3}$ arasında olduğu görülmüştür. Yüksek sıcaklık sonrası \%20 ve \%40 EPS ikameli (EUK 20, EUK40) geopolimer harçların basınç dayanımındaki kayıp oranları, referans geopolimer numuneye göre daha az olduğu belirlenmiştir. FESEM görüntülerinde yüksek sıcaklık sonrası dayanım kaybına yol açan gözenekli yapı ve mevcut dayanımı devam ettiren NASH jeli yapısı görüntülenmiştir. Birim ağırlık ile basınç dayanımı $\left(R^{2}=0,9008\right)$, 1S1 geçirgenlik katsayısı $\left(R^{2}=0,9787\right)$, ultrasonik geçiş hızı $\left(R^{2}=0,9082\right)$, ve yarmada çekme dayanımı $\left(R^{2}=0,9191\right)$ arasında yüksek oranda doğrusal ilişki olduğu sonucuna ulaşılmıştır.

Anahtar Kelimeler: Geopolimer hafif harç, mekanik özellik, 1sıl geçirimlilik, sıcaklık kürü

\section{Investigation of Physical, Mechanical and Thermal Conductivity Properties of Fly Ash Geopolymer Lightweight Mortar Substituted with EPS}

\author{
${ }^{* 1}$ Serhan İlkentapar, ${ }^{2}$ Halil Eren \\ ${ }^{* 1}$ Erciyes University Engineering Faculty Civil Engineering serhan@erciyes.edu.tr, \\ ${ }^{2}$ Erciyes University Engineering Faculty Civil Engineering, halileren7@gmail.com,
}

\begin{abstract}
In this study, fly ash-based geopolymer light mortars were produced using expanded polystyrene (EPS). EPS aggregated geopolymer mortars were produced by replacing the river sand with $20 \%, 40 \%, 60 \%, 80 \%, 100 \%$ by volume. Geopolymer mortars with EPS were subjected to a temperature heat curing at $75^{\circ} \mathrm{C}$ for 24 and 48 hours by activating the F class fly ash with $\mathrm{NaOH}$ at a fixed rate. Physical properties, mechanical properties, and thermal conductivity properties of geopolymer lightweight mortar samples after heat curing were investigated. In addition, the flexural, compressive strength of geopolymer mortars after high temperatures at $300^{\circ} \mathrm{C}, 600^{\circ} \mathrm{C}, 900^{\circ} \mathrm{C}$, and the microstructure of geopolymer pastes were investigated. According to the results, the unit weights of light geopolymer mortars subjected to 24 hours of heat curing are between 1.93 and $0.61 \mathrm{~g} / \mathrm{cm} 3$, and the unit weights of light geopolymer mortars subjected to 48 hours of heat curing are between 1.87 and $0.66 \mathrm{~g} / \mathrm{cm} 3 \mathrm{has}$ been seen. The compressive strength loss of geopolymer mortars with $20 \%$ and $40 \%$ EPS replacement (EUK 20, EUK40) after the high temperature was determined to be less than the reference geopolymer sample. The porous structure that causes loss of strength after high temperature and NASH gel structure that maintains the existing strength are displayed in FESEM images. Highly linear between unit weight and compressive strength $(\mathrm{R} 2=0.9191)$, heat transmission coefficient $(\mathrm{R} 2=0.9787)$, ultrasonic transmission velocity $(\mathrm{R} 2=0.9082)$, and split tensile strength $(\mathrm{R} 2=0.9191)$ It has been concluded that there is a relationship.
\end{abstract}

Keywords: Geopolymer lightweight mortar, mechanical properties, thermal conductivity, heat curing

*1SSorumlu Yazar: Erciyes Üniversitesi İnşaat Mühendisliği Bölümü, serhan@erciyes.edu.tr 


\section{GİRIŞ̧}

Atmosfere salınan $\mathrm{CO}_{2}$ 'nin yaklaşık \% 10'u çimento üretimi esnasında açığa çıkmaktadır. Çimento üretiminden kaynaklanan ve atmosfere salınan $\mathrm{CO}_{2}$ 'nin yaklaşık \% 7'si klinkerdeki $\mathrm{CaCO}_{3}$ 'ün $900{ }^{\circ} \mathrm{C}$ 'de ayrışmasıyla meydana gelmektedir[1,2]. Çimento üretimindeki bu zararlı etki araştırmacıları çimentosuz bir bağlayıcı olan geopolimer bağlayıcılar konusunda araştırmaya yönlendirmiştir[3-6]. Geopolimer terimi ilk olarak 1970'li y1llarda Joseph Dovidovits tarafından katı alüminasilikat ile alkali solüsyonun birlikte reaksiyonu ile sentezlenen bir malzeme olarak tanımlanmıştır[7]. Geopolimer sentezinde kullanılan en yaygın bağlayıcılar düşük kireçli $\mathrm{F}$ sınıfı uçucu kül ve metakaolin olup, aktivatörler ise alkali metal hidroksit ve alkali silikat türevleri olduğu literatürde belirtilmiştir[8]. Uçucu kül tabanlı geopolimerlerde zeolit ikamesi, metakaolin kalsinasyonunun geopolimer yapısına etkisi $[9,10]$, perlit esaslı geopolimerlerin mekanik dayanımları $[11,12]$ ve geopolimer köpük betonun mekanik ve mikro yapısı[13] ile ilgili son yıllarda yapılan çalışmalar geopolimer konusuna olan yüksek ilgiyi ve geopolimer konusundaki çeşitliliğgi göstermektedir. Araştırmacıların daha önce yapmış olduğu çalışmalarda geopolimerlere uyguladıkları kür sıcaklıkları $40{ }^{\circ} \mathrm{C}$ ile $115^{\circ} \mathrm{C}$ arasında değişmiş olup, geopolimerlerin basınç dayanımlarında yüksek sonuçlar elde ettiği görülmüştür[14-16]. Atiş vd. nin yapmış olduğu çalışmada standart rilem kumu, $\mathrm{NaOH}$ ve $\mathrm{F}$ sınıfı uçucu kül ile geopolimer harç üretmişlerdir. $\mathrm{Bu}$ geopolimer harçlar bağlayıcı miktarının \%10 oranında $\mathrm{Na}$ içeren alkali solüsyonu ile hazırlanmış ve 24, 48, 72 saat 75 ${ }^{\circ} \mathrm{C}$ 'de sicaklık kürüne tabi tutulmuştur. Elde edilen numunelerde en yüksek eğilme ve basınç dayanımları sırasıyla 10,3 MPa ve 68,1 MPa olduğu rapor edilmiştir[16]. TS EN 206:2013+A1'e göre beton yoğunluklarına göre üç gruba ayrılmaktadır. Buna göre normal beton, etüv kurusu durumdaki birim hacim kütlesi (yoğunluğu), $2000 \mathrm{~kg} / \mathrm{m}^{3}$ 'ten büyük olup $2600 \mathrm{~kg} / \mathrm{m}^{3}$ 'ü geçmeyen betondur. Hafif beton etüv kurusu durumdaki yoğunluğu, $800 \mathrm{~kg} / \mathrm{m}^{3}$ veya daha büyük olup $2000 \mathrm{~kg} / \mathrm{m}^{3}$ 'ü geçmeyen betondur. Ağır beton etüv kurusu durumdaki yoğunluğu, $2600 \mathrm{~kg} / \mathrm{m}^{3}$ 'ten daha büyük olan betondur[17]. Hafif betonlarda birim ağırlıklarına göre üç gruba ayrılmıştır. Buna göre birim ağırlığ $300 \mathrm{~kg} / \mathrm{m}^{3}$ ile $800 \mathrm{~kg} / \mathrm{m}^{3}$ arasında olanlar yalıtım betonu, $800 \mathrm{~kg} / \mathrm{m}^{3}$ ile $1400 \mathrm{~kg} / \mathrm{m}^{3}$ arasinda olanlar orta mukavemetli hafif beton, $1400 \mathrm{~kg} / \mathrm{m}^{3}$ den büyük olanlar taşıyıcı hafif beton olarak sinıflandırılmıştır[18]. Hafif agregalı geopolimer betonu ile yapılan çalışmalarda agrega olarak Posi vd. geri dönüşümlü hafif beton bloğu[19] Husikes v.d. biyolojik atık olan Polietilen tereftalat (Pet) [20] parçacıklarını kullanmışlardır. Hafif agregalar ile yapılan diğer geopolimer çalışmalarında pomza, vermikulit gibi volkanik kökenli malzemeler kullanılmıştır[21-23]. Bu çalışmada $\mathrm{NaOH}$ ile aktive edilmiş $\mathrm{F}$ sınıfı uçucu küllü geopolimer harçlara, hacimce $\% 20, \% 40, \% 60, \% 80, \% 100$ oranlarında granül EPS ikame edilmiştir. Üretilen geopolimer harç numunelerin fiziksel, mekanik ve 1s1 geçirimlilik özellikleri incelenmiştir. Ayrıca 40x40x160 mm ebatlarında üretilen geopolimer harçlar $300^{\circ} \mathrm{C}, 600^{\circ} \mathrm{C}$ ve $900^{\circ} \mathrm{C}$ 'de yüksek sicaklığa dayanıklılık deneyine tabi tutulmuştur. Yüksek sıcaklık sonrası geopolimer harçların eğilme ve basınç dayanımları incelenmiştir. 48 saat sıcaklık kürü uygulanan hafif harçların birim ağırlık sonuçları 0,66 $\mathrm{g} / \mathrm{cm}^{3}$ ile $1,87 \mathrm{~g} / \mathrm{cm}^{3}$ arasında olduğu belirlenmiştir. Ayrıca hafif harçların birim ağırlığı ile basınç dayanımı, yarma dayanımı ve 1sı iletkenlik katsayısı arasında doğrusal ilişki olduğu görülmüştür.

\section{MALZEME VE YÖNTEM}

\subsection{Uçucu Kül}

Yapılan çalışmada Zonguldak ilinde bulunan Çatalağzı Termik Santraline ait F sınıfı uçucu kül kullanılmıştır. Uçucu külün kimyasal analizi ve fiziksel özellikleri Tablo 1'de, küresel yapısı ve tane büyüklüğü görüntüsü FESEM fotoğrafinda Şekil 1'de verilmiştir.

Tablo 1. Uçucu külün kimyasal analizi ve fiziksel özellikleri

\begin{tabular}{|c|c|c|}
\hline $\begin{array}{c}\text { Kimyasal ve } \\
\text { Fiziksel } \\
\text { Özellikler }\end{array}$ & $\begin{array}{c}\text { Çatalağzi Uçucu } \\
\text { Külü }\end{array}$ & ASTM C618 \\
\hline $\mathrm{SiO}_{2}(\%)$ & 52,70 & \\
\hline $\mathrm{Al}_{2} \mathrm{O}_{3}(\%)$ & 25,80 & \\
\hline $\mathrm{Fe}_{2} \mathrm{O}_{3}(\%)$ & 6,70 & \\
\hline $\mathrm{SiO}_{2}+\mathrm{Al}_{2} \mathrm{O}_{3}+\mathrm{Fe}_{2} \mathrm{O}_{3} \geq \% 70$ & 85,2 & $\geq 70$ \\
\hline $\mathrm{K}_{2} \mathrm{O}(\%)$ & 4,45 & \\
\hline $\mathrm{Na}_{2} \mathrm{O}(\%)$ & 0,65 & \\
\hline $\mathrm{MgO}(\%)$ & 1,59 & \\
\hline $\mathrm{CaO}(\%)$ & 2,85 & \\
\hline $\mathrm{SO}_{3}(\%)$ & 0,33 & $<5$ \\
\hline $\mathrm{Cl}^{-}(\%)$ & 0,0043 & \\
\hline Serbest $\mathrm{CaO}(\%)$ & 0,02 & \\
\hline Kızdırma Kaybı (\%) & 4,80 & $<6$ \\
\hline Yoğunluk $\left(\mathrm{g} / \mathrm{cm}^{3}\right)$ & 2,14 & \\
\hline BET Yüzey Alanı $\left(\mathrm{m}^{2} / \mathrm{g}\right)$ & 1,72 & \\
\hline
\end{tabular}




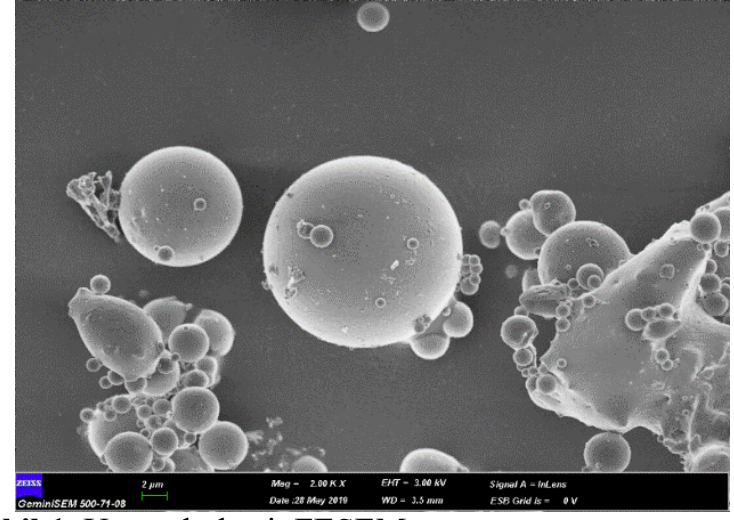

Şekil 1. Uçucu küle ait FESEM görüntüsü

\subsection{Irmak Kumu}

Çalışmada 0-4 mm arasında dane büyüklüğüne sahip ince 1rmak kumu kullanılmıştır. Kullanılan ince ırmak kumu için TS 3530 EN 933-1 'e göre elek analizi ve piknometre deneyi yapılmıştır[24]. Elde edilen elek analizi sonuçları Tablo 2'de verilmiştir. Irmak kumunun etüv kurusu tane yoğunluğu 2,58 $\mathrm{g} / \mathrm{cm}^{3}$ olarak elde edilmiştir. İncelik modülü 2,16 olarak hesaplanmıştır.

Tablo 2. Irmak kumu elek analizi

\begin{tabular}{|c|c|}
\hline $\begin{array}{c}\text { Elek Çapı } \\
\text { mm }\end{array}$ & $\begin{array}{l}\text { Elekten } \\
\text { Geçen }(\%)\end{array}$ \\
\hline 4 & 100 \\
\hline 2 & 82,4 \\
\hline 1 & 53,6 \\
\hline 0,5 & 35,7 \\
\hline 0,25 & 11,9 \\
\hline TAVA & 0 \\
\hline
\end{tabular}

\subsection{Sodyum Hidroksit ( $\mathrm{NaOH})$}

Uçucu külün aktive olması için, ticari olarak satılan en az \%98 saflıkta sodyum hidroksit $(\mathrm{NaOH})$ kullanılmıştır.

\subsection{Su}

Çalışmada karışım suyu olarak şehir şebekesinden alınan içilebilir musluk suyundan yararlanılmıştır. TS EN 1008 standardı karışım suyu olarak içilebilen suların kullanımına izin vermektedir.

\subsection{Genleştirilmiş Polistiren (EPS)}

Hafif agrega olarak granül EPS genleştirilmiş polistiren kullanılmıştır. EPS köpüklerin yoğunluk değeri 0,014 $\mathrm{g} / \mathrm{cm}^{3}$ 'dür.

\subsection{Ajan}

Hafif agrega olarak kullanılacak EPS'nin uçucu küllü harç arasında bir bağ oluşturması amacı ile ajan denilen beton katkısı kullanılmıştır. Ajan, bağlayıcı ile tam bir bütünlük sağlayan, daha sonra mukavemet eksiklikleri oluşturmayan, çatlamaya karşı dirençli E 200P kodlu kimyasal katkısı kullanılmıştır.

\subsection{Deneysel Çalışmalar}

Yapılan deneysel çalışmada geopolimer harç numuneleri hazırlanırken F sınıfı uçucu kül, ırmak kumu, $\mathrm{NaOH}$ ve içme suyu kullanılmıştır. Öncellikle 48 saat $75^{\circ} \mathrm{C}$ 'de sicaklık kürüne tabii tutularak alkali ile aktive edilmiş uçucu küllü referans harcın karışım reçetesi hazırlanmıştır. Uçucu küllü referans geopolimer harç, standart PÇ 42,5 R çimentolu harç numunesinin 28 günlük basınç dayanımına eşdeğer olacak şekilde ön çalışmalar yapılarak belirlenmiştir. Buna göre 1rmak kumu, uçucu kül, su, $\mathrm{NaOH}$ kütlece oranları sırasıyla $3,1,0,31,0,11$ olacak şekilde belirlenmiştir. Daha sonra granül EPS hacimce $\% 20, \% 40, \% 60, \% 80 \% 100$ oranlarında 1rmak kumundan azaltılarak ikame edilmiştir. İkame esnasında granül EPS'nin daha homojen dağılmasını sağlamak için bağlayıcı miktarının kütlece \% 1'i kadar ajan katkısı kullanılmıştır. Kullanılan ajanın su miktarı toplam karışım suyundan azaltılmıştır. Hafif geopolimer harçların numune kodlaması EPS'li uçucu küllü harç (EUK) olarak belirlenmiştir Karışım notasyonuna ait numaralandırma Tablo 3'de verilmiştir. Ayrıca karışıma giren malzemelerin resimleri a) Uçucu Kül, b) Irmak Kumu, c) $\mathrm{NaOH}$, d) EPS olarak Şekil 2. de gösterilmiştir.

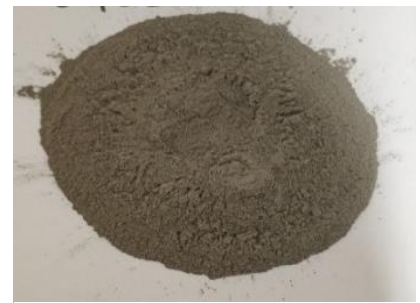

a) Uçucu Kül

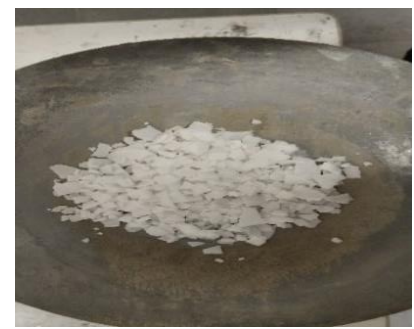

c) $\mathrm{NaOH}$

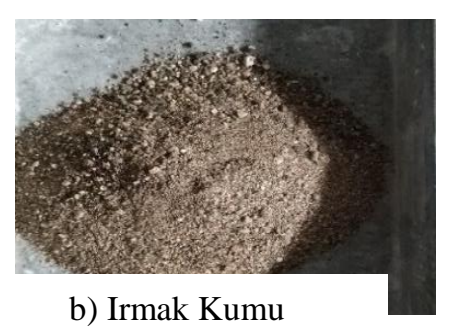

b) Irmak Kumu

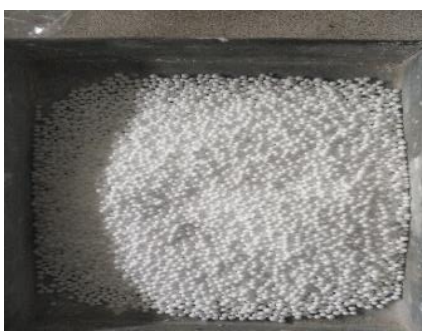

d) EPS
Şekil 2. Karışıma giren malzemeler 
Tablo 3. Agrega notasyonu ve karışım no

\begin{tabular}{|c|c|}
\hline Agrega Notasyonu & Karışı No \\
\hline$\% 100$ Kum - \% 0 EPS & EUK- 0 \\
\hline$\% 80$ Kum - \% 20 EPS & EUK- 20 \\
\hline$\% 60$ Kum - \% 40 EPS & EUK- 40 \\
\hline$\% 40$ Kum - \% 60 EPS & EUK- 60 \\
\hline$\% 20$ Kum - \% 80 EPS & EUK- 80 \\
\hline$\% 0$ Kum - \% 100 EPS & EUK- 100 \\
\hline
\end{tabular}

\subsection{1. İş̧lenebilirlik Tayini}

Taze harcın işlenebilirliği TS EN 1015-3 (Taze harç kıvamının tayini) standardına göre yayılma tablası ile ölçülmüştür[25]. Deneyde üst iç çapı $70 \mathrm{~mm}$, taban iç çapı $100 \mathrm{~mm}$ ve yüksekliği $60 \mathrm{~mm}$ olan konik kap kullanılmıştır. Konik kap dairesel levhanın merkezine yerleştirilmiştir. Harç 2 tabakada ve her tabakaya 10 vuruş olacak şekilde tokmak ile sıkıştırılarak doldurulmuştur. Çevirme kolu ile her saniyede 1 düşüş olacak şekilde 15 defa yayılma tablasına düşüş yaptırılmıştır. Yayılan harç kütlesi birbirine dik iki doğrultuda ölçülmüş ve elde edilen değerlerin ortalaması $\mathrm{mm}$ cinsinden işlenebilirlik değeri olarak kaydedilmiştir.

\subsubsection{Birim Ăğırlık Tayini}

Çalışmada üretilen uçucu küllü, EPS'li hafif harç numunelerine gerekli kür şartları uygulandıktan sonra 24 saat $105^{\circ} \mathrm{C}$ 'de etüvde kurutulan numunelerin ağırlıkları etüv sonrası oda sıcaklığına kadar soğuması için beklenip havadaki ağırlıkları alınmış ve numunenin hacmine bölünerek birim ağırlıkları hesaplanmıştır.

\subsubsection{Su Emme ve Boşluk Oranı Tayini}

Deneyler kapsamında yer alan harçlara ait su emme ve boşluk oranları tayini, uçucu küllü harçların 24 ve 48 saat etüvde $75^{\circ} \mathrm{C}$ 'de sıcaklık kürü sonrasında, 40×40×160 mm'lik prizma numuneler üzerinde yürütülmüştür. Numunelerin fiziksel özelliklerini tespit etmek için etüv kurusu ağırlıkları, kuru yüzey doygun ağırlıkları ve arşimet terazisi ile su içindeki ağırlıkları ölçülmüştür. Bu üç değerin yardımıyla su emme ve boşluk oranları hesaplanmıştır. Sertleşmiş numunede su emme oranı, etüv kurusu numunelerin suya doygun kuru yüzeyli duruma getirilmesi ile ortaya çıkan ağırlık artışının, etüv kurusu harç ağırlığına oranıdır.

$$
\begin{aligned}
& \text { Boşluk Oranı }(\%)=\frac{\left(A_{K Y D}-A_{F K}\right)}{\left(A_{K Y D}-A_{S U}\right)} \times 100 \\
& \text { Su Emme Oranı }(\%)=\frac{A_{K Y D}-A_{F K}}{A_{F K}} \times 100
\end{aligned}
$$

Burada;

$A_{F K}$ : Fırın kurusu ağırlığı (g)

$A_{K Y D}$ : Kuru yüzey doygun ağırlı̆̆ı (g)

$A_{\text {SU: }}$ Su içindeki ağırlığı (g)

\subsubsection{Eğilme ve Basınç Dayanımı Tayini}

Uçucu külle üretilen $75{ }^{\circ} \mathrm{C}$ 'de 24 ve 48 saat kür edilen $40 \times 40 \times 160 \mathrm{~mm}$ boyutlarındaki sertleşmiş numunelere TS EN 1015-11 standardına uygun olarak mesnet açıklığ 100 mm olacak şekilde tek noktadan eğilme deneyi yapılmıştır[26]. Yükleme sırasında ani sıçrama olmaksızın kırılma gerçekleşecek şekilde $50 \pm 10 \quad \mathrm{~N} / \mathrm{s}$ yükleme hızı seçilmiştir. Eğilme deneyi ile ikiye bölünen numunelere düzgün kalıp yüzeylerinden TS EN 1015-11 standardında belirtilen şartlara uygun şekilde basınç dayanımı deneyi uygulanmıştır[26]. Basınç dayanımı deneyinde 40×40 mm genişlikte başlıklar kullanılmıştır. Yükleme hızı olarak 500 $\mathrm{N} / \mathrm{s}$ yük uygulanarak numuneler kırılmıştır. Her bir seri için eğilme deneyi sonucunda elde edilen 6 adet yarım numuneye basınç deneyi uygulanmış ve elde edilen 6 adet basınç deneyi aritmetik ortalaması basınç dayanım değeri olarak hesaplanmıştır.

\subsubsection{Yarmada Çekme Dayanımı Tayini}

$75{ }^{\circ} \mathrm{C}$ 'de 48 saat sicaklık kürüne tabii tutulan harç numunelerinde $\% 0, \% 20, \% 40, \% 60, \% 80$ ve $\% 100$ ikameli EPS bulunan $15,5 \times 14 \times 4 \mathrm{~cm}$ (en, boy, kalınlık) boyutlarındaki hafif harç numuneler üretilmiştir. Üretilen numuneler TS 2824 standardında belirtilen şartlara uygun olarak teste tabii tutulmuştur[27].

\subsubsection{Yüksek Sıcaklığa Dayanıklılık Tayini}

Çalışmada üretilen uçucu küllü harçların 48 saat etüvde $75^{\circ} \mathrm{C}$ 'de sıcaklık kürü sonrasında, yüksek sicaklığa dayanıklılık testleri $40 \times 40 \times 160 \mathrm{~mm}$ boyutlarındaki numuneler üzerinde kül firını kullanılarak gerçekleştirilmiştir. Numunelerin yüksek sıcaklığa karşı dayanıklılığını belirleyebilmek için $5^{\circ} \mathrm{C} /$ dakika sıcaklık artışı uygulayarak numunelerin ayrı ayr $300^{\circ} \mathrm{C}, 600^{\circ} \mathrm{C}$ ve $900^{\circ} \mathrm{C}$ sıcaklıklara ulaşmaları sağlanmış ve ulaşılan bu sıcaklıkta 60 dakika süre ile bekletilmişlerdir. Fırında kalma süresini tamamlayan numuneler firından çıkartılarak oda sıcaklığına gelinceye kadar bekletilmiştir. Oda sicaklığına gelen numuneler üzerinde eğilme ve basınç dayanım deneyleri gerçekleştirilmiştir.

\subsubsection{Kılcal Su Emme Katsayısı Tayini}

Kılcal su emme deneyi ASTM C1585'e göre gerçekleştirilmiştir[28]. Numunelerin yan ve üst yüzeyi alüminyum folyo bant ile kaplanarak havadaki nemden korunmuştur. 3 adet $40 \times 40 \times 160 \mathrm{~mm}$ ölçülerinde üretilen harç numuneleri kılcal su emme deneyine tabii tutulup ortalama değeri alınmıştır. Her numuneye 1, 5, 10, 20 ve 30 . dakikada, 1, 2, 3, 4, 5 ve 6 . saatte (birincil kilcallık katsayıs1) ve $1,2,3,4,5,6,7$ ve 8 . günde (ikincil kılcallık katsayıs1) ağırlık okumaları yapılarak kılcal su emme miktarları tayin edilmiştir. 


\subsubsection{Ultrasonik Atımlı Dalga Hızı Tayini}

Yapılan çalışmada üretilen numunelerin ultrasonik atımlı dalga hızları TS EN 12504-4 standardına uygun şekilde Pundit (Portable Ultrasonic Non-destructive Digital Indicating Tester) adı verilen Proceq marka cihaz ile belirlenmiştir[29]. Cihazda alıcı ve verici transduserler bulunmaktadır. Verici transduser tarafindan gönderilen ultrasonik sinyaller numune içerisinden geçerek alıcı transduser tarafindan alınır ve cihaz tarafindan ultrasonik sinyallerin alış-veriş süresi $\mu \mathrm{s}$ cinsinden hassas olarak ölçülür. Transduserler ile ölçüm yapılan numune yüzeyinin daha pürüzsüz olmasını sağlamak için ultrasonik jel kullanılmıştır. Ultrasonik atımlı dalga hızı ölçümleri 40x40x160 mm'lik numunelerin $160 \mathrm{~mm}$ 'lik boyu doğrultusunda, sicaklık kürü işlemi sonrasında numuneler oda sıcaklığına geldikten sonra yapılmıştır. Ultrasonik sinyallerin numune içerisinden geçiş süresi numune içerisindeki boşluklara, çatlaklara, numunenin elastik özelliklerine ve yoğunluğuna bağlıdır. Ultrasonik atımlı dalga hızı testi ile numunelerin homojenliği, içindeki boşluklar, çatlaklar ile numunelerin dayanımı ve kalitesi ile ilgili bilgiler elde edilebilmektedir. Ultrasonik atımlı dalga hızı test ölçümleri her bir seri için 3 adet numune üzerinde gerçekleştirilerek elde edilen değerlerin ortalaması alınmıştır. Ultrasonik atımlı dalga hızları aşağıdaki denklem kullanılarak hesaplanmıştır.

$\mathrm{V}=\frac{\mathrm{L}}{\mathrm{T}}$

Burada;

V: Ultrasonik geçiş hızı, $\mathrm{m} / \mathrm{s}$

L: Geçiş uzunluğu, $\mathrm{m}$

T: Geçiş zamanı, s

\subsubsection{Isı İletkenlik Tayini}

Proje kapsamında termal iletkenlik katsayılarının belirlenmesi için 48 saat etüvde $75^{\circ} \mathrm{C}$ 'de sıcaklık küründe bekletilerek üretilen harç numunelerinde $\% 0, \% 20, \% 40$, $\% 60, \% 80$ ve $\% 100$ ikameli EPS bulunan $15,5 \times 14 \times 4 \mathrm{~cm}(\mathrm{en}$, boy, kalınlık) boyutlarındaki hafif harç numuneler üretilmiştir. Üretilen numunelerin 1sıl geçirimlilik katsayıları Thermtest markalı HFM-100 Heat Flow Meter modelli cihaz ile belirlenmiştir.

\subsubsection{FESEM görüntüsü ve EDX analizi}

Hazırlanan harç numunelerine yüksek sıcaklık sonrası hamur yapısını incelemek amaciyla FESEM (Field Emission Scanning Electron Microscope) görüntülemesi ve EDX (Energy Dispersive X-ray Analysis) analizi yapılmıştır. Uçucu kül, $\mathrm{NaOH}$ ve su ile imal edilen geopolimer hamur numuneler 48 saat $75^{\circ} \mathrm{C}$ 'de hava almayacak kapalı bir kapta sıcaklık kürüne tabii tutulmuştur. Hamur numuneler $300^{\circ} \mathrm{C}$, $600{ }^{\circ} \mathrm{C}$ ve $900{ }^{\circ} \mathrm{C}$ 'de yüksek sıcaklığa maruz bırakılmıştır. Elde edilen numuneler $10 \mathrm{~mm}-15 \mathrm{~mm}$ boyutlarında kırılarak altın paladyum kaplaması yapılmış olup kırık yüzey incelemesi yapılmıştır. FESEM görüntülemeleri yapılırken hamur yapısında gerek duyulan yerlerden EDX analizi yapılmıştır.

\section{BULGULAR}

EPS straforun ikamesi ile işlenebilirlik değerleri referans harç (EUK0) numunesine göre sırasıyla \%31, \%35, \%63, $\% 64$ ve \%68 oranında artmıştır. EUK60 numunesine kadar işlenebilirlik değerinde çarpıcı şekilde artmış olmasına rağmen EUK60'dan sonra işlenebilirlik değerindeki artış azalmıştır. İşlenebilirliğe ait sonuçlar Tablo 4'de verilmiştir.

Tablo 4. İşlenebilirlik sonuçları (mm)

\begin{tabular}{|c|c|c|c|c|c|c|}
\hline $\begin{array}{c}\text { Numune } \\
\text { Adı }\end{array}$ & $\begin{array}{c}\text { EUK } \\
\mathbf{0}\end{array}$ & $\begin{array}{c}\text { EUK } \\
\mathbf{2 0}\end{array}$ & $\begin{array}{c}\text { EUK } \\
\mathbf{4 0}\end{array}$ & $\begin{array}{c}\text { EUK } \\
\mathbf{6 0}\end{array}$ & $\begin{array}{c}\text { EUK } \\
\mathbf{8 0}\end{array}$ & $\begin{array}{c}\text { EUK } \\
\mathbf{1 0 0}\end{array}$ \\
\hline $\begin{array}{c}\text { İşlenebilirlik } \\
\text { Değeri } \\
(\mathrm{mm})\end{array}$ & 104 & 137 & 141 & 170 & 171 & 175 \\
\hline
\end{tabular}

24 saat $75^{\circ} \mathrm{C}$ sicaklık kürü uygulanan harç numunelerin birim ağırlıkları incelendiğinde hepsi $2 \mathrm{~g} / \mathrm{cm}^{3}$ 'ün altında olduğu Tablo 5'de gösterilmiştir. Ayrıca boşluk oranı ve su emme değerlerinin birim ağırlığın azalması ile artmakta olduğu görülmektedir.

Tablo 5. $75{ }^{\circ} \mathrm{C}$ 'de 24 saat sicaklık kürü uygulanmış numunelerin birim ağırlık, boşluk oranı ve su emme değerleri

\begin{tabular}{|c|c|c|c|}
\hline Numune Ad 1 & $\begin{array}{c}\text { Birim ağırlık } \\
\left(\mathrm{g} / \mathrm{cm}^{3}\right)\end{array}$ & $\begin{array}{c}\text { Boşluk } \\
\text { Oran } 1 \\
(\%)\end{array}$ & $\begin{array}{c}\text { Su Emme } \\
(\%)\end{array}$ \\
\hline EUK0 & 1,93 & 17,68 & 8,95 \\
\hline EUK20 & 1,79 & 18,70 & 10,58 \\
\hline EUK40 & 1,59 & 20,25 & 13,12 \\
\hline EUK60 & 1,30 & 21,10 & 17,10 \\
\hline EUK80 & 0,89 & 21,82 & 25,62 \\
\hline EUK100 & 0,61 & 28,20 & 39,29 \\
\hline
\end{tabular}

48 saat $75^{\circ} \mathrm{C}$ sıcaklık kürü uygulanan harç numunelerinin birim ağırlıkları incelendiğinde referans (EUK0) hariç diğerlerinin hepsi $2 \mathrm{~g} / \mathrm{cm}^{3}$ 'ün altında olduğu Tablo 6'da gösterilmiştir. Ayrıca boşluk oranı ve su emme değerlerinin birim ağırlığın azalması ile arttığı sonucuna ulaşılmıştır. Birim ağırlık değerleri ile boşluk oranı ve su emme oranı arasında yüksek oranda doğrusal ilişki olduğu Şekil 3'de gösterilmiştir.

Tablo 6. $75{ }^{\circ} \mathrm{C}$ 'de 48 saat sicaklık kürü uygulanmış numunelerin birim ağırlık, boşluk oranı ve su emme değerleri

\begin{tabular}{|c|c|c|c|}
\hline $\begin{array}{c}\text { Numune } \\
\text { Ad1 }\end{array}$ & $\begin{array}{c}\text { Birim ăğılık } \\
\left(\mathrm{g} / \mathrm{cm}^{3}\right)\end{array}$ & $\begin{array}{c}\text { Boşluk } \\
\text { Oranı } \\
(\%)\end{array}$ & $\begin{array}{c}\text { Su } \\
\text { Emme } \\
(\%)\end{array}$ \\
\hline EUK0 & 2,10 & 10,82 & 5,17 \\
\hline EUK20 & 1,87 & 13,11 & 7,15 \\
\hline EUK40 & 1,58 & 13,75 & 8,61 \\
\hline
\end{tabular}


Tablo 7(devamı). $75^{\circ} \mathrm{C}$ 'de 48 saat sıcaklık kürü uygulanmış numunelerin birim ağırlık, boşluk oranı ve su emme değerleri

\begin{tabular}{|c|c|c|c|}
\hline EUK60 & 1,27 & 15,24 & 11,87 \\
\hline EUK80 & 0,95 & 16,25 & 16,82 \\
\hline EUK100 & 0,66 & 19,17 & 23,72 \\
\hline
\end{tabular}

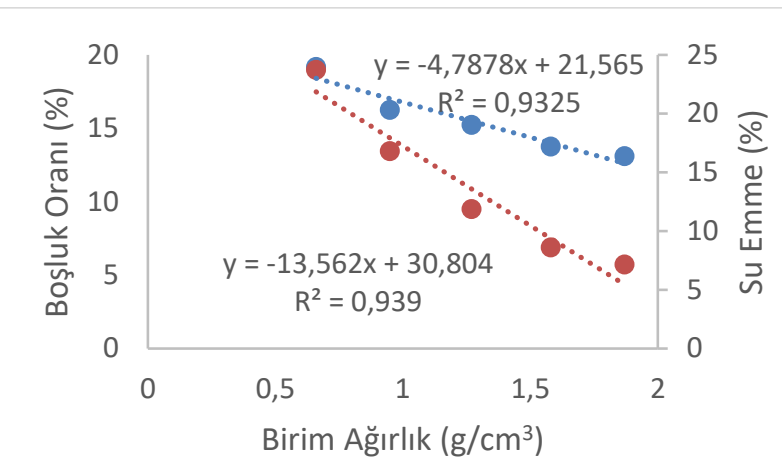

Şekil 2. EPS ikameli hafif harçlarda birim ağırlık ile boşluk oranı ve su emme arasındaki ilişki

$75^{\circ} \mathrm{C}$ 'de 24 saat ve 48 saat kür edilen harç numunelerinde granül EPS ikamesi ile eğilme ve basınç dayanımlarında azalmalar olmuştur. Basınç dayanım sonuçları incelendiğinde referans (EUK0) numunesinde 48 saat sıcaklık kürü, 24 saat sicaklık kürüne göre $\% 46$ artış sağlamışıır. Ancak 48 saat sıcaklık kürüne tabii tutulmuş EPS'li numunelerin basınç dayanımında yüksek oranda artış görülmezken dikkat çekici artış EUK40, EUK60, numunelerinde sirasıly $\% 13, \% 24$ oranlarında olduğu belirlenmiştir. Eğilme dayanımı sonuçları incelendiğinde 48 saat sıcaklık kürü uygulamanın 24 saat sıcaklık kürüne göre daha etkili olduğu görülmektedir. 48 saat sıcaklık kürü uygulanan numunelerin 24 saat sicaklık kürü uygulanan numunelere göre EUK20 ve EUK40 numunelerinde eğilme dayanımı artı̧̧ sırasıyla $\% 90, \% 140$ olduğu belirlenmiş̧ir. 48 saat kür uygulanan numunelerin 24 saat kür uygulanan numunelerden daha fazla eğilme ve basınç dayanıma sahip olduğu sonucuna varılmıştır. Bu durum $75{ }^{\circ} \mathrm{C}$ 'de sıcaklık kürünün 48 saate kadar geopolimer yapıyı geliştirmesi ve mekanik dayanımı artırması ile açıklanabilir. Literatürde daha önce yapılan çalışmalarda, $75^{\circ} \mathrm{C}$ sıcaklık kürü ile imal edilen geopolimer harçların mekanik dayanımının 48 saat sonunda 24 saate göre daha yüksek olduğu ve bu çalışmadaki sonuçlarla uyumlu olduğu anlaşılmıștır[16,34]. Ayrıca geopolimer hafif harçlarda birim ağırlığın azalması ile daha boşluklu bir yapı meydan gelmiş olup bu durum mekanik dayanımı olumsuz etkilemiştir. Literatürde, birim ağırlık değerinin azalması ile basınç dayanımlarında azalmalar olduğu daha önceki çalışmalarda rapor edilmiştir[30-33].
Geopolimer harç numunelerin her iki kür süresine ait eğilme ve basınç dayanımı sonuçları Tablo 7'de verilmiştir. İlaveten her bir geopolimer harç karışımının eğilme dayanımına ait grafiği Şekil 4'de ve basınç dayanımına ait grafiği Şekil 5'de verilmiştir. Ayrıca 48 saat sıcaklık kürü uygulanan hafif EPS'li numunelerin birim ağırlığı ile basınç dayanımı arasında yüksek oranda doğrusal ilişki $\left(R^{2}=0,9008\right)$ olduğu Şekil 6'da gösterilmiştir.

Tablo 8. $75{ }^{\circ} \mathrm{C}$ 'de 24 ve 48 saat sıcaklık kürü uygulanan numunelerin eğilme ve basınç dayanım değerleri

\begin{tabular}{|c|c|c|c|c|}
\hline \multirow{2}{*}{$\begin{array}{c}\text { Numune } \\
\text { Ad1 }\end{array}$} & \multicolumn{2}{|c|}{ 24 saat } & \multicolumn{2}{c|}{ 48 saat } \\
\cline { 2 - 5 } & $\begin{array}{c}\text { Eğilme } \\
(\mathrm{MPa})\end{array}$ & $\begin{array}{c}\text { Basıç } \\
(\mathrm{MPa})\end{array}$ & $\begin{array}{c}\text { Eğilme } \\
(\mathrm{MPa})\end{array}$ & $\begin{array}{c}\text { Basınç } \\
(\mathrm{MPa})\end{array}$ \\
\hline EUK0 & 2,91 & 31,82 & 4,95 & 46,56 \\
\hline EUK20 & 1,70 & 21,14 & 3,27 & 22,63 \\
\hline EUK40 & 1,31 & 10,63 & 3,16 & 12,07 \\
\hline EUK60 & 0,96 & 5,92 & 0,9 & 7,39 \\
\hline EUK80 & 0,52 & 3,40 & 0,49 & 3,63 \\
\hline EUK100 & 0,50 & 1,54 & 0,45 & 1,84 \\
\hline
\end{tabular}

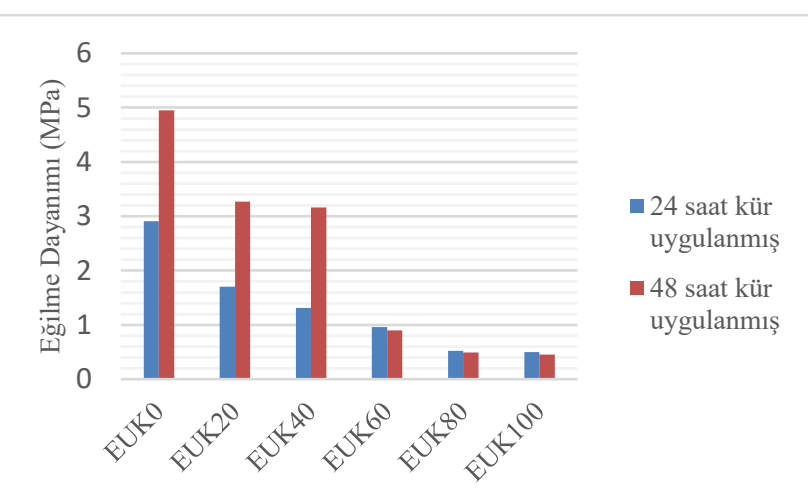

Şekil 3. 24 ve 48 saat $75{ }^{\circ} \mathrm{C}$ sicaklık kürü uygulanan geopolimer harçların eğilme dayanımı

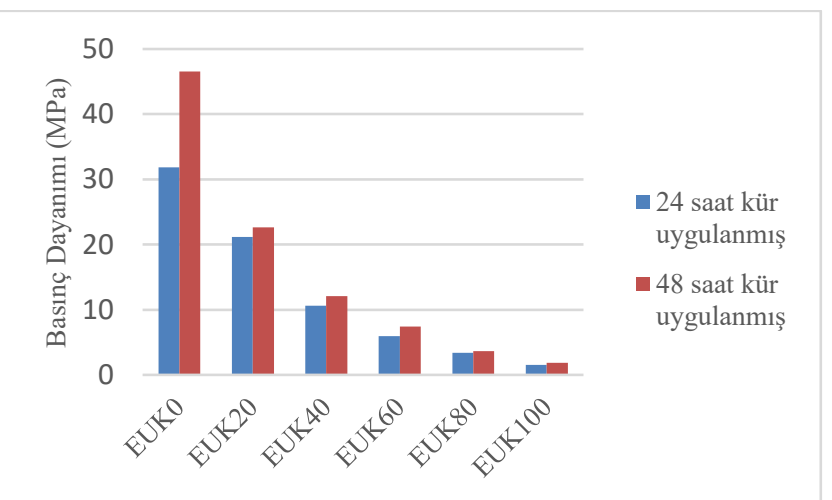

Şekil 4. 24 ve 48 saat $75{ }^{\circ} \mathrm{C}$ sıcaklık kürü uygulanan geopolimer harçların basınç dayanımı 


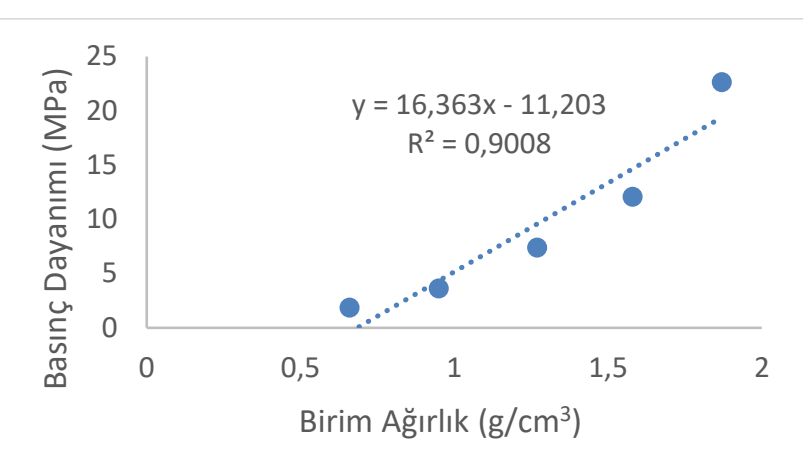

Şekil 5. 48 saat sıcaklık kürü uygulanan EPS ikameli hafif harçların birim ağırlık ile basınç dayanımı arasındaki ilişkisi

48 saat $75^{\circ} \mathrm{C}$ 'de sicaklık kürüne tabi tutulan numunelerin yarmada çekme dayanımlarını incelediğimizde EPS ikamesinin artması ile yarmada çekme dayanımının azaldığı Tablo 8'de görülmektedir. Ayrıca birim ağırlık ile yarmada çekme dayanımının arasında yüksek oranda doğrusal ilişki (R2=0,9191) olduğu Şekil 7'de gösterilmiştir.

Tablo 8. Harç numunelere ait yarma dayanımı değerleri (MPa)

\begin{tabular}{|c|c|}
\hline Numune Adı & $\begin{array}{c}\text { Yarmada Çekme Dayanımı } \\
(\mathrm{MPa})\end{array}$ \\
\hline EUK0 & 3,24 \\
\hline EUK20 & 1,87 \\
\hline EUK40 & 1,10 \\
\hline EUK60 & 0,78 \\
\hline EUK80 & 0,46 \\
\hline EUK100 & 0,30 \\
\hline
\end{tabular}

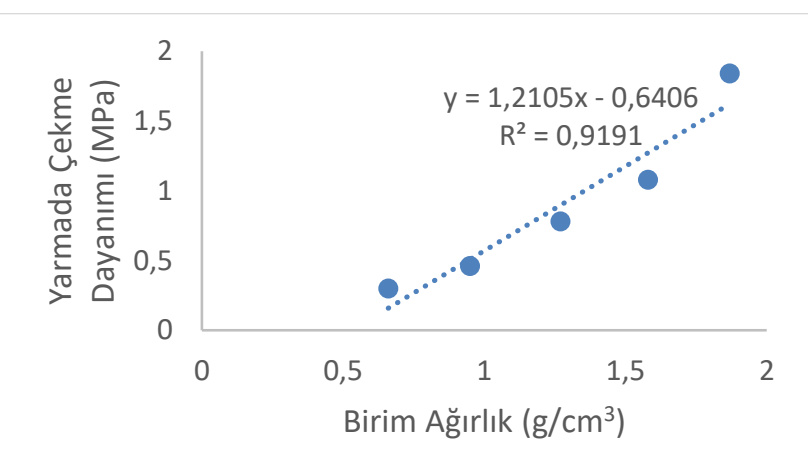

Şekil 6. EPS ikameli hafif harçların birim ağırlık ile yarmada çekme dayanımı arasındaki ilişkisi

Harç numuneleri $75{ }^{\circ} \mathrm{C}$ 'de 48 saat sıcaklık kürüne tabi tutulduktan sonra $300{ }^{\circ} \mathrm{C}, 600{ }^{\circ} \mathrm{C}$ ve $900{ }^{\circ} \mathrm{C}$ 'de yüksek sıcaklığa maruz bırakılmıştır. Daha sonra oda sıcaklığına gelen numunelerin eğilme ve basınç dayanım deneyleri yapılmıştır. Buna göre referans (EUK0) numunede, yüksek sıcaklığa maruz bırakıldıktan sonra sırasıyla \%32, \%39, \%59 oranında basınç dayanım kaybı görülmüştür. $\mathrm{Bu}$ azalma değeri geopolimer bağlayıcının yüksek sıcaklığa olan dayanım kaybını göstermektedir. Özellikle referans geopolimer harç numunesinde $300{ }^{\circ} \mathrm{C}$ 'de $\% 32$ oranında yaşanan ilk dayanım kaybı geopolimer harcın $75^{\circ} \mathrm{C}$ 'de 48 saat kür edilmesi ile açıklanabilir. Geopolimer harçların ilk sıcaklık kürünün kısa süreli ve düşük sıcaklıkta olması sonrasında maruz kalacağı yüksek sıcaklığa karşı direnci artırmaktadır. Literatürde daha önce yapılan çalışmalarda da $50{ }^{\circ} \mathrm{C}, 60{ }^{\circ} \mathrm{C}$ 'de sıcaklık kürü yapılmas1[35] ya da 24 saat sıcaklık kürü yapılması[36] yüksek sıcaklığa direnci artırdığı rapor edilmiştir. Bu yönüyle $75^{\circ} \mathrm{C}$ 'de 48 saat sıcaklık kürü $300{ }^{\circ} \mathrm{C}$ sıcaklık sonrası basınç dayanımı direncini azaltmıştır. $600{ }^{\circ} \mathrm{C}$ sıcaklık sonrası basınç dayanımlarını incelediğimizde $300{ }^{\circ} \mathrm{Css}$ caklık sonrası basınç dayanımına göre dayanım kaybı oranının fazla olmadığı görülmektedir. Ayrıca EUK20 ve EUK40 numaralı EPS'li geopolimer harçlardaki basınç dayanım kayıp oranları yüksek sıcaklık sonrası $\left(300{ }^{\circ} \mathrm{C}, 600{ }^{\circ} \mathrm{C}\right.$ ve $\left.900{ }^{\circ} \mathrm{C}\right)$ referans harç numunesindeki azalma oranından daha az olduğu görülmektedir. Bu sonuçlara göre $300{ }^{\circ} \mathrm{C}$ ve $600{ }^{\circ} \mathrm{C}$ EPS'li harçlardaki EPS'nin erimesi yapısal anlamda ciddi bir basınç dayanımı kaybına yol açmamıştır. Her bir yüksek sıcaklık sonras1 EUK60, EUK80, EUK100 numaralı EPS'li harçlardaki basınç dayanım kayıpları referans numunedeki basınç dayanım kaybından (\%32, \%39, \%59) daha fazla olduğu görülmektedir. Buna göre \%40'dan daha fazla EPS ikamesi, yüksek sıcaklıklarda dayanım kayıplarını yüksek oranda artırmıştır. Ayrıca $900{ }^{\circ} \mathrm{C}$ sıcaklıktan sonra geopolimer harcın tahrip olduğu görülmüştür. Daha önce geopolimerler üzerinde yapılan yüksek sıcaklığa dayanıklılık çalışmalarında da görüldüğü üzere yüksek sıcaklıklarda aktivatör cinsi ve aktivatör oranına bağlı olarak içyapıda çatlakların meydana geldiği ve özellikle $800^{\circ} \mathrm{C}$ 'den sonra çatlakların daha derin olduğu rapor edilmiştir[37, 38]. Yüksek sıcaklık sonrası eğilme dayanımına ait sonuçlar Tablo 9 ve Şekil 8'de, basınç dayanımına ait sonuçlar Tablo 10 ve Şekil 9' da verilmiştir.

Tablo 9. $75{ }^{\circ} \mathrm{C}$ 'de 48 saat sıcaklık kürü uygulanan harç numunelerin $300{ }^{\circ} \mathrm{C}, 600{ }^{\circ} \mathrm{C}$ ve $900{ }^{\circ} \mathrm{C}$ sonrası eğilme dayanımı değerleri

\begin{tabular}{|l|c|c|c|c|}
\hline & $\begin{array}{c}\text { Yüksek } \\
\text { Sıcaklık } \\
\text { Öncesi } \\
\text { Dayanım }\end{array}$ & $300{ }^{\circ} \mathrm{C}$ & $600^{\circ} \mathrm{C}$ & $900{ }^{\circ} \mathrm{C}$ \\
\hline $\begin{array}{l}\text { Numune } \\
\text { Adı }\end{array}$ & $\begin{array}{c}\text { Eğilme } \\
\text { Dayanımı } \\
\text { (MPa) }\end{array}$ & $\begin{array}{c}\text { Eğilme } \\
\text { Dayanımı } \\
(\mathrm{MPa})\end{array}$ & $\begin{array}{c}\text { Eğilme } \\
\text { Dayanımı } \\
\text { (MPa) }\end{array}$ & $\begin{array}{c}\text { Eğilme } \\
\text { Dayanımı } \\
(\mathrm{MPa})\end{array}$ \\
\hline EUK0 & 4,95 & 3,34 & 1,8 & 0,8 \\
\hline EUK20 & 3,27 & 2,37 & 0,84 & 0,56 \\
\hline EUK40 & 3,16 & 1,02 & 0,71 & 0 \\
\hline EUK60 & 0,9 & 0,53 & 0,29 & 0 \\
\hline EUK80 & 0,49 & 0 & 0 & 0 \\
\hline EUK100 & 0,45 & 0 & 0 & 0 \\
\hline
\end{tabular}




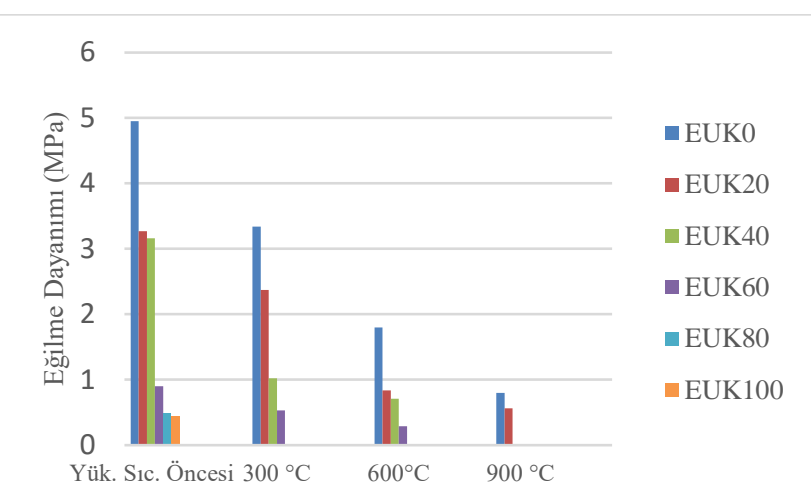

Şekil 7. $75{ }^{\circ} \mathrm{C}$ 'de 48 saat sıcaklık kürü uygulanan harç numunelerin $300{ }^{\circ} \mathrm{C}, 600{ }^{\circ} \mathrm{C}$ ve $900{ }^{\circ} \mathrm{C}$ sonrası eğilme dayanımı

Tablo 10. $75^{\circ} \mathrm{C}$ 'de 48 saat sıcaklık kürü uygulanan harç numunelerin $300{ }^{\circ} \mathrm{C}, 600{ }^{\circ} \mathrm{C}$ ve $900{ }^{\circ} \mathrm{C}$ sonrası basınç dayanımı değerleri

\begin{tabular}{|c|c|c|c|c|}
\hline & $\begin{array}{l}\text { Yük. Sic. } \\
\text { Öncesi }\end{array}$ & $300{ }^{\circ} \mathrm{C}$ & $600^{\circ} \mathrm{C}$ & $900{ }^{\circ} \mathrm{C}$ \\
\hline $\begin{array}{l}\text { Numune } \\
\text { Adı }\end{array}$ & $\begin{array}{c}\text { Basınç } \\
\text { Dayanımı } \\
\text { (MPa) }\end{array}$ & $\begin{array}{c}\text { Basınç } \\
\text { Dayanımı } \\
\text { (MPa) }\end{array}$ & $\begin{array}{c}\text { Basınç } \\
\text { Dayanımı } \\
\text { (MPa) }\end{array}$ & $\begin{array}{c}\text { Basınç } \\
\text { Dayanım } \\
\text { (MPa) }\end{array}$ \\
\hline EUK0 & 46,56 & 31,48 & 28,56 & 18,76 \\
\hline EUK20 & 22,63 & 17,49 & 18,16 & 14,17 \\
\hline EUK40 & 12,07 & 12,53 & 10,34 & 6,96 \\
\hline EUK60 & 7,39 & 4,77 & 3,78 & 2,81 \\
\hline EUK80 & 3,63 & 1,42 & 1,65 & 1,4 \\
\hline EUK100 & 1,84 & 0,91 & 0,85 & 0,89 \\
\hline
\end{tabular}

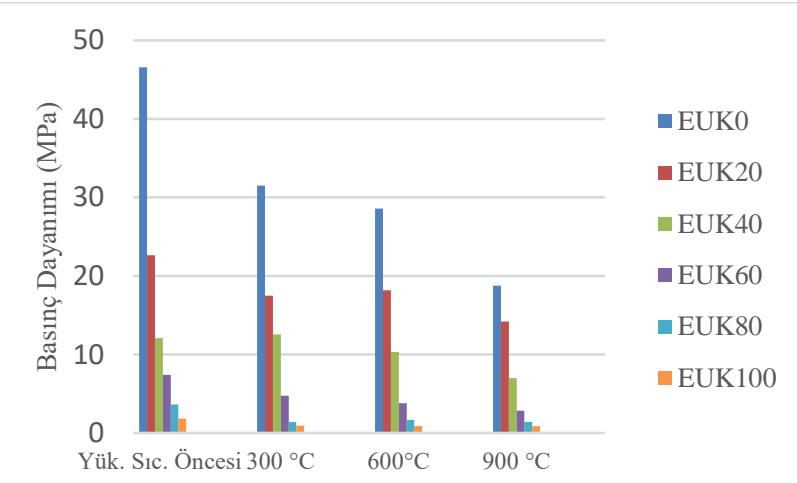

Şekil 8. $75{ }^{\circ} \mathrm{C}$ 'de 48 saat sicaklık kürü uygulanan harç numunelerin $300{ }^{\circ} \mathrm{C}, 600{ }^{\circ} \mathrm{C}$ ve $900{ }^{\circ} \mathrm{C}$ sonrası basınç dayanımı

48 saat $75^{\circ} \mathrm{C}$ 'de sıcaklık kürüne tabi tutulan numunelerin kılcal su emme katsayılarını Tablo 11 'de incelediğimizde EPS ikamesinin artması ile birincil ve ikincil kılcal su emme katsayılarının arttığı görülmüştür. Ayrıca birim ağırlığın azalması ile kılcal su emme katsayılarının arttığı görülmektedir.
Tablo 11. $75^{\circ} \mathrm{C}$ 'de 48 saat sıcaklık kürü uygulanan harç numunelerin birincil ve ikincil su emme katsayıları

\begin{tabular}{|c|c|c|}
\hline Numune Ad1 & $\begin{array}{c}\text { Birincil K1lcal } \\
\text { Su Emme } \\
\text { Katsay1s1 } \\
\mathrm{mm} / \mathrm{s}^{1 / 2}\end{array}$ & $\begin{array}{c}\text { İkincil K1lcal Su } \\
\text { Emme Katsay1s1 } \\
\mathrm{mm} / \mathrm{s}^{1 / 2}\end{array}$ \\
\hline EUK0 & 0,0331 & 0,0013 \\
\hline EUK20 & 0,0386 & 0,0016 \\
\hline EUK40 & 0,0413 & 0,0017 \\
\hline EUK60 & 0,0450 & 0,0018 \\
\hline EUK80 & 0,0459 & 0,0022 \\
\hline EUK100 & 0,0484 & 0,0026 \\
\hline
\end{tabular}

$75^{\circ} \mathrm{C}$ 'de 24 saat ve 48 saat kür edilen harç numunelerinde granül EPS ikamesi ile ultrasonik geçiş hızı değerlerinde azalmalar olmuştur. Kür sürelerine ait ultrasonik geçiş hızı değerleri Tablo 12'de verilmiştir. 24 saat sıcaklık kürü uygulanan numunelerin harç karışım serisini incelediğimizde EPS kaynaklı boşlukların etkisi olmakla beraber geopolimer hamurundan da kaynaklı boşlukların etkisi görülmektedir. 48 saat sıcaklık kürüne tabi tutulan numunelerde geoplimer hamurunun daha yoğun hale geldiği anlaşılmıştır. Buna ilave olarak EPS ikamesi arttıkça ultrasonik geçiş hızı değerinde düşüş olduğu gözlemlenmiştir. EPS ikameli hafif harçlarda birim ağırlık ile ultrasonik geçiş hızı arasındaki yüksek oranda $\left(\mathrm{R}^{2}=0,9082\right)$ ilişki olduğu Şekil 10'da gösterilmektedir.

Tablo 12. $75^{\circ} \mathrm{C}$ 'de 24 ve 48 saat sicaklık kürü uygulanan harç numunelerin ultrasonik geçiş hızı değerleri

\begin{tabular}{|c|c|c|}
\hline \multirow{2}{*}{$\begin{array}{c}\text { Numune } \\
\text { Ad1 }\end{array}$} & $\begin{array}{c}24 \text { saat Sicaklık } \\
\text { kürü }\end{array}$ & 48 saat S1caklık kürü \\
\cline { 2 - 3 } & $\begin{array}{c}\text { Ultrasonik geçiş hızı } \\
(\mathrm{m} / \mathrm{s})\end{array}$ & $\begin{array}{c}\text { Ultrasonik geçiş hızı } \\
(\mathrm{m} / \mathrm{s})\end{array}$ \\
\hline EUK0 & 3241 & 3791 \\
\hline EUK20 & 3003 & 3306 \\
\hline EUK40 & 2596 & 3163 \\
\hline EUK60 & 2151 & 2897 \\
\hline EUK80 & 1594 & 2152 \\
\hline EUK100 & 734 & 1169 \\
\hline
\end{tabular}

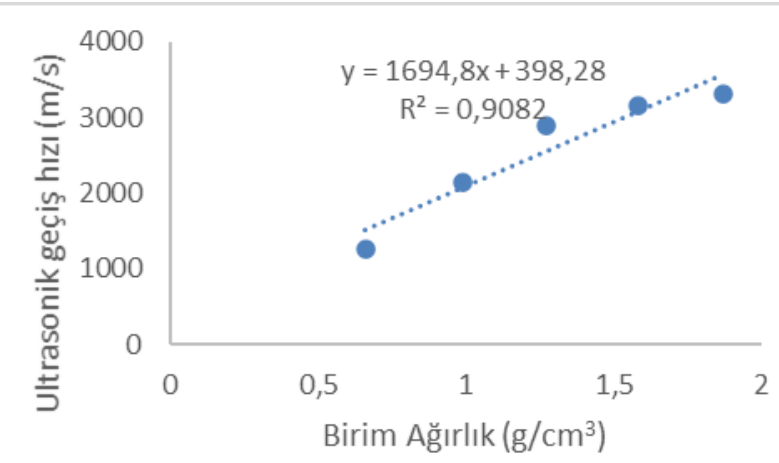

Şekil 9. EPS ikameli hafif harçlarda birim ağırlık ile ultrasonik geçiş hızı arasındaki ilişki 
Harç numunelere ait ısı geçirgenlik katsayıları Tablo 13'de incelendiğinde EPS ikamesi arttıkça 1sı iletkenlik değerinin düştüğü görülmektedir. Daha önceki yapılan çalışmalarda benzer sonuçlar görülmüş olup birim ağırlığın düşmesi ile 1s1 iletkenlik katsayısı da azalmaktadır[39]. Ayrıca basınç dayanımın azalması ile 1sı iletkenlik katsayısının azalması arasındaki ilişki daha önceki araştırmalarda da görülmüştür[39-41]. Birim ağırlık ile 1sı iletkenlik katsayıları arasında yüksek oranda $(\mathrm{R}=0,9787)$ doğrusal ilişki olduğu Şekil 11'de gösterilmiştir.

Tablo 13. Harç numunelere ait 1sı iletkenlik katsayıları değerleri $(\mathrm{W} / \mathrm{mK})$

\begin{tabular}{|c|c|}
\hline Numune Ad 1 & $\begin{array}{l}\text { Is1 İletkenlik Katsayıs1 } \\
(\mathrm{W} / \mathrm{mK})\end{array}$ \\
\hline EUK0 & 0,5109 \\
\hline EUK20 & 0,3563 \\
\hline EUK40 & 0,2830 \\
\hline EUK60 & 0,2287 \\
\hline EUK80 & 0,1959 \\
\hline EUK100 & 0,1126 \\
\hline
\end{tabular}

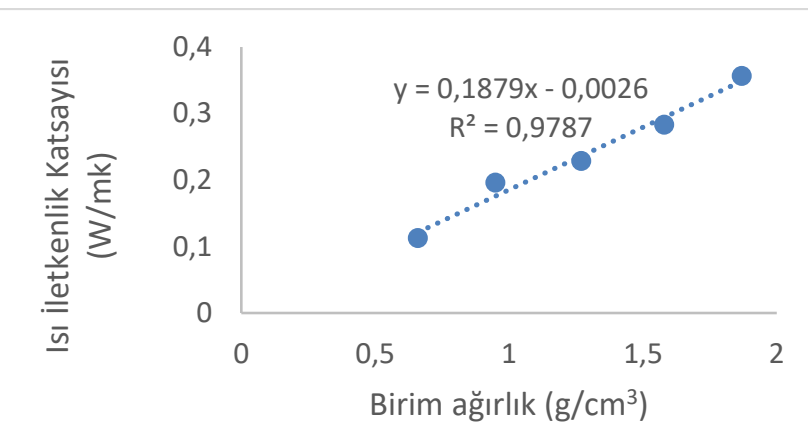

Şekil 10. EPS ikameli hafif harçlarda birim ağırlık ile 1sı iletkenlik katsayısı arasındaki ilişki

$75{ }^{\circ} \mathrm{C}^{\prime}$ de 48 saat sıcaklık kürüne tabii tutulan geoplimer hamurun öncellikle referans numunesini incelediğimizde referans numuneye ait NASH jelinin SEM görüntüsü Şekil 12'de, EDX analiz pikleri Şekil 13'de, EDX analizine ait atom ağırlığı yüzdesi Tablo 14'de verilmiştir. Yüksek sicaklık öncesi ve yüksek sicaklık sonrası FESEM görüntüleri Şekil 14'de görülmekte olup, referans numunesinin mikro yapısına baktığımız zaman genel itibariyle uçucu kül taneciklerinin bozulduğu, uçucu kül tanelerinin alkaliler ile tepkimeye girerek NASH jellerini oluşturduğu görülmektedir. $300{ }^{\circ} \mathrm{C}$ (a) ve $600{ }^{\circ} \mathrm{C}$ 'de (b) yüksek sicaklığa tabii tutulan numunelerde daha yoğun jel yapısı görünmesine rağmen kısmı boşluklar (gözenekler) ve çatlaklar görülmektedir. Bu boşluk ve çatlakların dayanım kaybına yol açtığı yüksek sıcaklık sonrası mekanik dayanım bölümünde belirtilmişti. Literatürde daha önce yapılan çalışmalarda termogravimetrik analiz sonucunda $100{ }^{\circ} \mathrm{C}$ civarında, NASH jelinde absorbe ve bağlı suyun buharlaşması ile geopolimer hamurda kısmi boşlukların meydana geldiği rapor edilmiştir[36, 42, 43]. Bu yönüyle $300{ }^{\circ} \mathrm{C}\left(\right.$ b) ve $600{ }^{\circ} \mathrm{C}$ 'de (c) oluşan gözenekli yapının bir sebebi de geopolimer hamurun yapısındaki NASH jelinde bulunan absorbe ve bağlı suyun çıkışı esnasında olduğu görülmektedir. Geopolimer hamur $900{ }^{\circ} \mathrm{C}$ 'de (d) yüksek sıcaklığa tabi tutulduğunda hamur mikro yapısında derin gözenekler ve çatlaklarla birlikte sürekli hale gelen bir tahribat oluştuğu görülmüş olup, daha önceki yapılan çalışmalarda da[37,38] aynı şekilde tahribatların olduğu görülmektedir.

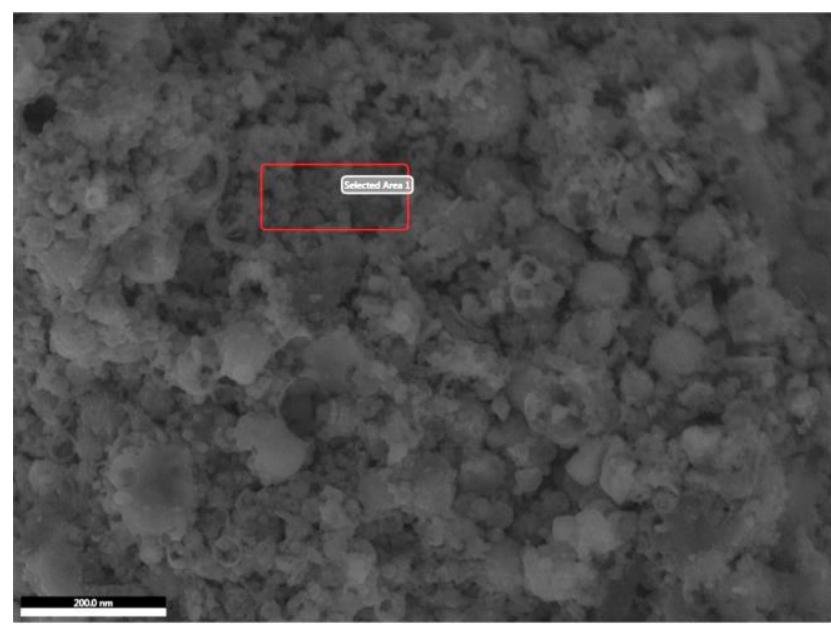

Şekil 11. Referans numunenin NASH jeli EDX analizi (seçili alan)

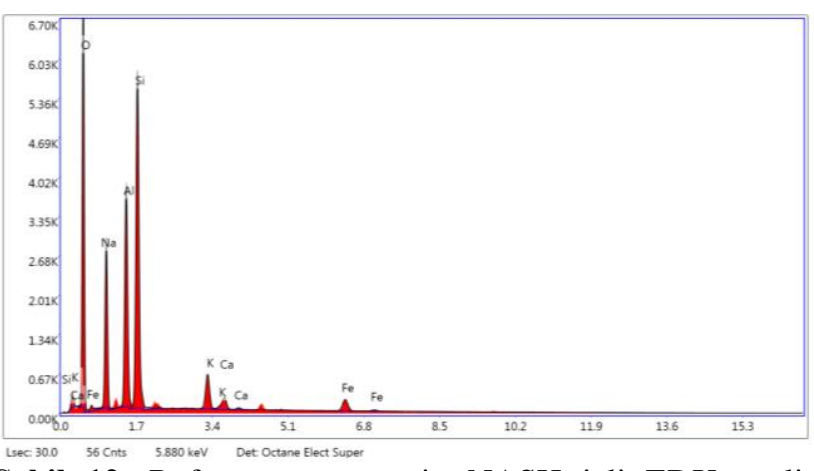

Şekil 12. Referans numunenin NASH jeli EDX analizi pikleri

Tablo 14. Referans numunenin NASH jeli atom ağırlığı yüzdeleri

\begin{tabular}{|c|c|c|c|}
\hline \multicolumn{4}{|c|}{ eZAF Smart Quant Results } \\
\hline Element & Weight \% & Atomic $\%$ & Net Int. \\
\hline $\mathrm{O} \mathrm{K}$ & 44.1 & 57.08 & 1201.96 \\
\hline $\mathrm{NaK}$ & 16.87 & 15.2 & 601.27 \\
\hline $\mathrm{AlK}$ & 13.37 & 10.26 & 923.22 \\
\hline $\mathrm{SiK}$ & 20.11 & 14.83 & 1486.97 \\
\hline $\mathrm{K} \mathrm{K}$ & 2.68 & 1.42 & 208.86 \\
\hline $\mathrm{CaK}$ & 1.05 & 0.54 & 74.15 \\
\hline $\mathrm{FeK}$ & 1.83 & 0.68 & 92.8 \\
\hline
\end{tabular}




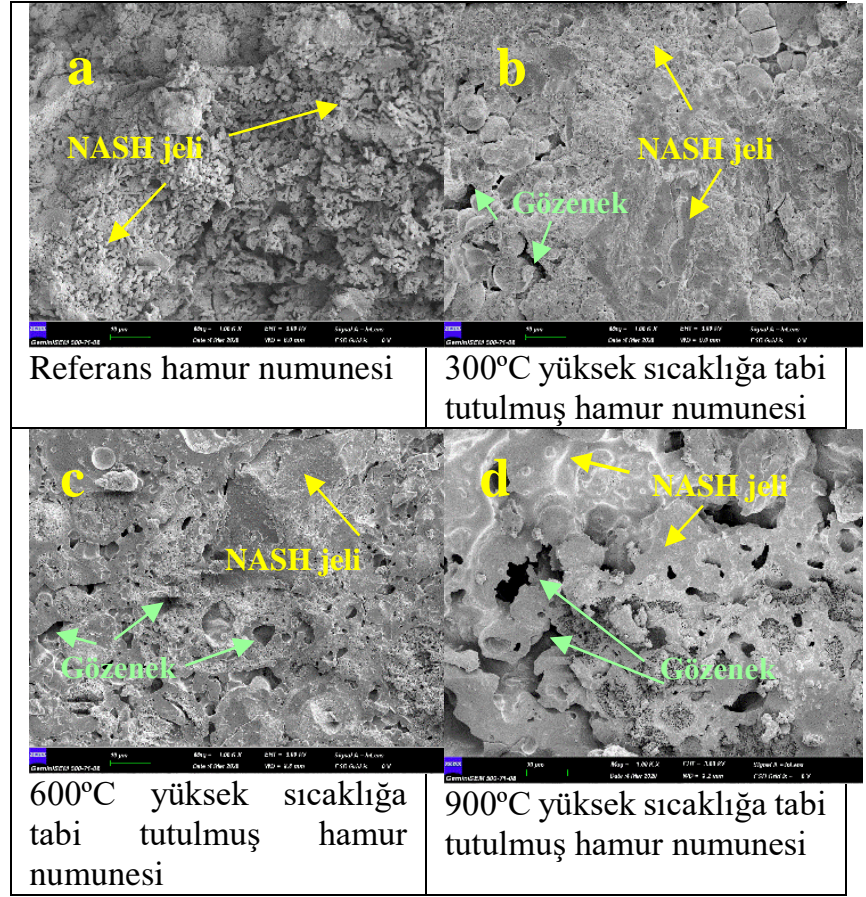

Şekil 13. Referans hamur numunesi, $300{ }^{\circ} \mathrm{C}, 600{ }^{\circ} \mathrm{C}$ ve 900 ${ }^{\circ} \mathrm{C}$ 'de yüksek sicaklığa tabi tutulan hamur numunelerin 1000 büyütmede FESEM görüntüleri

\section{DEĞERLENDİRME VE SONUÇ}

- İşlenebilirlik değeri EPS ikamesi oranının artmasıyla artmıştır. Referans (EPS0) geopolimer harca göre işlenebilirlik değeri EPS20, EPS40, EPS60, EPS80, EPS100 numunelerinde sirasiyla $\% 31, \% 35, \% 63, \% 64$, \%68 oranında artmıştır.

- Birim ağırlık değeri EPS ikamesi oranı artmasıyla hem 24 saat hem de 48 saat sicaklık kürüne tabi tutulan harçlarda azalmıştır. Buna ilave olarak boşluk oranı ve su emme miktarları EPS ikame oranı artmasıyla artış göstermiştir.

- 24 saat ve 48 saat sıcaklık kürü yapılan iki durumda da, EPS ikame oranın artmasıyla eğilme ve basınç dayanımlarında azalma gözlemlenmiştir. Basınç dayanımı açısından incelendiğinde genel olarak hafif geopolimer harçlarda 48 saat sicaklık kürü etkisi çok fazla olmadığı görülmüştür.

- Yüksek sıcaklık sonrası dayanımları incelendiğinde sıcaklık artışı ile eğilme ve basınç dayanımlarında azalma olduğu gözlemlenmiştir. $\mathrm{Bu}$ dayanım azalmasının sebebi hem EPS'nin yüksek sicaklıkta yok olmasıyla hem de geopolimer hamurun mikro yapısında oluşan tahribattan olduğu sonucuna varılmıştır.

- Yarmada çekme dayanımı 48 saat sıcaklık kürü uygulanan numunelerde EPS oranın artmas1 ile azalma göstermiş olup birim ağırlıkla arasında yüksek oranda doğrusal ilişki olduğu gözlemlenmiştir.

- Isı iletkenlik değeri 48 saat sıcaklık kürü uygulanan numunelerde EPS ikame oranın artması ile düştüğü görülmüştür.

\section{TEŞEKKÜR}

Bu proje Türkiye Bilimsel ve Teknolojik Araştırma Kurum (TÜBİTAK) 2209 B Sanayiye yönelik lisans araştırma projeleri 2241 nolu proje kapsamında desteklenmiştir.

\section{KAYNAKÇA}

[1].V.M. Malhotra, Introduction: sustainable development and concrete technology, ACI Concr. Int. 24 (7) (2002).

[2].X. Guo, H. Shi, W.A. Dick, Compressive strength and microstructural characteristics of class $\mathrm{C}$ fly ash geopolymer, Cem. Concr. Compos. 32, 142-147, 2010

[3].M.J.A. Mijarsh, M.A. Johari, Z.A. Ahmad, Synthesis of geopolymer from large amounts of treated palm oil fuel ash: application of the Taguchi method in investigating the main parameters affecting compressive strength, Constr. Build. Mater. 52, 473-481, 2014

[4].S. Hanjitsuwan, S. Hunpratub, P. Thongbai, S. Maensiri, V. Sata, P. Chindaprasirt, Effects of $\mathrm{NaOH}$ concentrations on physical and electrical properties of high calcium fly ash geopolymer paste, Cem. Concr. Compos. 45, 9-14, 2014

[5].T. Phoongernkham, P. Chindaprasirt, V. Sata, S. Hanjitsuwan, S. Hatanaka, The effect of adding nano-SiO2 and nano- $\mathrm{Al}_{2} \mathrm{O}_{3}$ on properties of high calcium fly ash geopolymer cured at ambient temperature, Mater. Des. 55 58-65, 2014

[6].J. He, Y. Jie, J. Zhang, Y. Yu, G. Zhang, Synthesis and characterization of red mud and rice husk ash-based geopolymer composites, Cem. Concr. Compos. 37, 2013

[7].J. Davidovits, Geopolymer Chemistry and Applications, third ed., Geopolymer Institute, Saint-Quentin, France, Juli, 2011.

[8].J.L. Provis, S.A. Bernal, Geopolymers and related alkaliactivated materials, Annu. Rev. Mater. Res. 44 299-327, 2014

[9].Ü.Yurt And M. Emiroğlu, "Zeolit İkameli Geopolimer Betonlarda Kür Şartlarının Etkileri,” Acad. Platf. J. Eng. Sci., pp. 396-402, 2020.

[10].G. Görhan, “Afyon Kocatepe Üniversitesi Fen ve Mühendislik Bilimleri Dergisi Geopolimer Harç Özelliklerine Metakaolin Kalsinasyon Sıcaklığının Etkisi Effect of Calcination Temperature of Metakaolin on the Properties of Geopolymer Mortar,” vol. 20, pp. 83-89, 2020. [11].M. M. Yadollahi and S. Varolgüneş, "Polipropilen Liflerin Perlit Esaslı Geopolimerlerin Mekanik Davranışına Etkisi The Effect of Polypropylene Fibers on Mechanical Behavior of Perlite Based Geopolymers," vol. 7, no. 2, pp. 36-41, 2018.

[12].S. Güzelküçük, "Perlit Esaslı Geopolimer KompozitlereKür Süresi ve Sicaklığın Etkisi Effect Of Curing Time and Temperature on Perlite-Based Geopolimer Composites," pp. 5-12, 2019.

[13].M. Serhat Başpınar et al., "Aralık (5-10 s) AKU," J.Eng.App.Sci, vol. 1, no. 5, 2018.

[14].Panias D, Giannopoulou IP, Perraki T. Effect of synthesis parameters on the mechanical properties of fly ashbased geopolymers. Colloids Surf A;301:246-54. 2007 
[15].Chindaprasirt P, Chareerat T, Sirivivananon V. Workability and strength of coarse high calcium fly ash geopolymer. Cem Concr Compos;29: 224-9(2007)

[16].C. D. Atiş, E. B. Görür, O. Karahan, C. Bilim, S. İlkentapar, and E. Luga, "Very high strength (120 MPa) class F fly ash geopolymer mortar activated at different $\mathrm{NaOH}$ amount, heat curing temperature and heat curing duration," Constr. Build. Mater., vol. 96, pp. 673-678, Oct. 2015.

[17].TS EN 206-1, Beton - Bölüm 1: Özellik, Performans, İmalat ve Uygunluk, Türk Standartları Enstitüsü, Ankara 2002.

[18].Taşdemir C., Şengül Ö., "Hafif Betonların Fiziksel ve Mekanik Özellikleri”, Beton 2013 Hazır Beton Kongresi, İstanbul, 21-23 Şubat 2013.

[19].P. Posi, C. Teerachanwit, C. Tanutong, S. Limkamoltip, S. Lertnimoolchai, V. Sata, P. Chindaprasirt, Lightweight geopolymer concrete containing aggregate from recycle lightweight block, Mater. Des. 52 580-586, 2013

[20].D.M.A. Huiskes, A. Keulen, Q.L. Yu, H.J.H. Brouwers, Design and performance evaluation of ultra-lightweight geopolymer concrete, Mater. Des. 89 516-526, 2016

[21].M. Aslam, P. Shafigh, M.A. Nomeli, M.Z. Jumaat, Manufacturing of high- strength lightweight aggregate concrete using blended coarse lightweight aggregates, J. Clean. Prod. 13, 2017

[22].H.A. Mboya, K.N. Njau, A.L. Mrema, C.K. King'ondu, Influence of scoria and pumice on key performance indicators of Portland cement concrete, Constr. Build. Mater. 197, 2019

[23].A.M. Rashad, Vermiculite as a construction material e a short guide for Civil Engineer, Constr. Build. Mater. 125, 2016

[24].TS 3530 EN 933-1, Agregaların geometrik özellikleri için deneyler bölüm 1: Tane büyüklüğü dağılımı tayiniEleme metodu, Türk Standartları Enstitüsü, 1999.

[25].TS EN 1015-3, Kagir harc1- Deney metotlar1- Bölüm 3: Taze harç kıvamının tayini (yayılma tablası ile), Türk Standartları Enstitüsü, Ankara 2000

[26].TS EN 1015-11 Kagir harc1 - Deney metotları -Bölüm 11: Sertleşmiş harcın basınç ve eğilme dayanımının tayini, Türk Standartları Enstitüsü, Ankara. 2000

[27].TS 2824 EN 1338/AC Zemin Döşemesi İçin Beton Kaplama Blokları - Gerekli Şartlar Ve Deney Metotları, Türk Standartları Enstitüsü, Ankara, 2009

[28].ASTM C1585-13. Standard Test Method for Measurement of Rate of Absorption of Water by HydraulicCement Concretes, Annual Book of ASTM Standarts, February, 2013

[29].TS EN 12504-4,. Testing concrete - Part 4: Determination of ultrasonic pulse velocity. Ankara: TSE, 2012

[30].D. Hardjito, S.E. Wallah, D.M.J. Sumajouw, B.V.
Rangan, Factors infuencing the compressive strength of fly ash-based geopolymer concrete, Civ. Eng. Dimens. 6 September,(2004)

[31].E.G. Nawy, Concrete Construction Engineering Handbook, CRC Press, Taylor \& Francis Group, Boca Raton, (24 June). 2008

[32].D. Hardjito, B.V. Rangan, Development and Properties ofLow-Calcium Fly Ash Based Geopolymer Concrete, Research Report GC1(Perth) 2005.

[33].V.F.F. Barbosa, K.J.D. MacKenzie, C. Thaumaturgo, Synthesis and characterisation of materials based on inorganic polymers of alumina and silica: sodium polysialate polymers, Int. J. Inorg. Mater. 2 309-317. (2000)

[34].S. İlkentapar, C. D. Atiş, O. Karahan, and E. B. Görür Avşaroğlu, "Influence of duration of heat curing and extra rest period after heat curing on the strength and transport characteristic of alkali activated class F fly ash geopolymer mortar," Constr. Build. Mater., vol. 151, pp. 363-369, 2017. [35].M. Kaya, M. Uysal, K. Yilmaz, and C. D. Atis, "Behaviour of Geopolymer Mortars after Exposure to Elevated Temperatures," vol. 24, no. 4, 2018.

[36].A. Hosan, S. Haque, and F. Shaikh, "Compressive behaviour of sodium and potassium activators synthetized fly ash geopolymer at elevated temperatures_A comparative study," J. Build. Eng., vol. 8, no. October, pp. 123-130, 2016.

[37].M. Lahoti, K. K. Wong, K. H. Tan, and E. H. Yang, "Effect of alkali cation type on strength endurance of fly ash geopolymers subject to high temperature exposure," Mater. Des., vol. 154, pp. 8-19, Sep. 2018.

[38].T. Bakharev, "Thermal behaviour of geopolymers prepared using class F fly ash and elevated temperature curing," Cem. Concr. Res., vol. 36, no. 6, pp. 1134-1147, Jun. 2006.

[39].D. M. A. Huiskes, A. Keulen, Q. L. Yu, and H. J. H. Brouwers, "Design and performance evaluation of ultralightweight geopolymer concrete," Mater. Des., vol. 89, pp. 516-526, Jan. 2016.

[40].C. Shi, P.V. Krivenko, D. Roy, Alkali-Activated Cements and Concretes, Taylor \& Frencis, Oxon, UK, 2006. [41].R. Aguilar, O. Burciaga Díaz, J.I. Escalante García, Lightweight concretes of activated metakaolin-Fy ash binders, with blast furnace slag aggregates, Constr. Build. Mater. 24 (16 December). (2010)

[42].Y. Zhao, J. Ye, X. Lu, M. Liu, Y. Lin,W. Gong, G. Ning, Preparation ofsintered foamma- terials by alkaliactivated coal fly ash, J. Hazard. Mater. 174 (6 Septbemer). (2009)

[43].S. Chandrasekhar and P. N. Pramada, "Sintering behaviour of calcium exchanged low silica zeolites synthesized from kaolin,” vol. 27, pp. 105-114, 2001. 